\title{
Nylon Filter Arrays Reveal Differential Expression of Expressed Sequence Tags in Wheat Roots Under Aluminum Stress
}

\author{
Kai XIAO ${ }^{1,2}$, Gui-Hua BAI $^{2 *}$ and Brett F CARVER ${ }^{3}$ \\ (1. College of Agronomy, Hebei Agricultural University, Baoding 071001, China; \\ 2. USDA/ARS and Department of Agronomy, Kansas State University, Manhattan, KS 66506, USA; \\ 3. Department of Plant and Soil Science, Oklahoma State University, Stillwater, OK 74078, USA)
}

\begin{abstract}
To enrich differentially expressed sequence tags (ESTs) for aluminum (Al) tolerance, cDNA subtraction libraries were generated from Al-stressed roots of two wheat (Triticum aestivum L.) nearisogenic lines (NILs) contrasting in Al-tolerance gene(s) from the Al-tolerant cultivar Atlas 66, using suppression subtractive hybridization (SSH). Expression patterns of the ESTs were investigated with nylon filter arrays containing $614 \mathrm{cDNA}$ clones from the subtraction library. Gene expression profiles from macroarray analysis indicated that $25 \mathrm{ESTs}$ were upregulated in the tolerant NIL in response to Al stress. The result from Northern analysis of selected upregulated ESTs was similar to that from macroarray analysis. These highly expressed ESTs showed high homology with genes involved in signal transduction, oxidative stress alleviation, membrane structure, $\mathrm{Mg}^{2+}$ transportation, and other functions. Under Al stress, the Al-tolerant NIL may possess altered structure or function of the cell wall, plasma membrane, and mitochondrion. The wheat response to $\mathrm{Al}$ stress may involve complicated defense-related signaling and metabolic pathways. The present experiment did not detect any induced or activated genes involved in the synthesis of malate and other organic acids in wheat under Al-stress.
\end{abstract}

Key words: aluminum tolerance; differential gene expression; near-isogenic lines; suppression subtractive hybridization ( $\mathrm{SSH}$ ); wheat.

Aluminum $\left(\mathrm{Al}^{3+}\right)$ toxicity occurs in approximately $30 \%$ of arable land worldwide and is a major limiting factor for crop production in acidic soils (Carver et al. 1995; Von Uexkull et al. 1995). Aluminum may alter the cation-exchange capacity of cell walls (Horst 1995), change the potential of the cell membrane, affect uptake of $\mathrm{Ca}^{2+}$ and/or $\mathrm{Mg}^{2+}$, induce oxidative stress via lipid peroxidation, replace $\mathrm{Mg}^{2+}$ or $\mathrm{Fe}^{3+}$ in cellular reactions, interfere with signal transduction (Jones et al. 1995), and directly bind to DNA and/or RNA. These interactions are manifested as inhibited root growth and stunted shoot growth (Carver et al. 1995). The exudation of organic compounds, such as malate, oxalate, or citrate, that are capable of chelating $\mathrm{Al}^{3+}$ into non-toxic complexes, was proposed as one of the important mechanisms to relieve $\mathrm{Al}^{3+}$ toxicity in plants (Delhaize et al. 1993; Basu et al. 1994; Delhaize and Ryan 1995; Horst 1995; Kochian 1995; Ryan et al. 1995; Pellet et al. 1996; Zhang et al. 2001; Tang et al. 2002). Other mechanisms may also exist, especially in light of polygenic control of $\mathrm{Al}^{3+}$ tolerance in wheat (Carver et al. 1995).

So far, though more than $20 \mathrm{Al}$-induced genes have been reported from a range of plant species. The molecular mechanism of Al tolerance in plants remains largely unknown. In wheat, those earlier studies on gene expression in response to abiotic stress mostly used differential screening or differential display methods.

Received 8 Oct. 2004 Accepted 21 Feb. 2005

Supported by the Targeted Research Initiative Program of the Oklahoma Agricultural Experimental Station and the Oklahoma Wheat Research Foundation.

*Author for correspondence. Tel: +1 785532 1124; Fax: +1 785532 6167; E-mail: <gbai@agron.ksu.edu>. 
Those studies were often limited to a small number of genes (less than 10) for one study (Snowden et al. 1993; Cruz-Ortega et al. 1997). Because Al tolerance may involve complicated signal and metabolic pathways (Ezaki et al. 2001), quantitative methods for simultaneous genome-wide analysis of gene expression patterns may improve our molecular understanding of the wheat defense response to Al toxicity (Schenk et al. 2000). Suppression subtractive hybridization ( $\mathrm{SSH})$ is a powerful approach to enrich and isolate differentially expressed sequence tags (ESTs; Diatchenko et al. 1996, 1998). Therefore, a high level of enrichment, low background, and normalized abundance of cDNAs in the subtracted library make the method attractive for rapid cloning of cDNAs of differentially expressed genes for Al tolerance.

Atlas 66 is one of a few winter wheat cultivars identified with a high level of Al tolerance and is the most adopted Al-tolerant cultivar to wheat growing environments in the US. Using a back-crossing strategy, Al tolerance genes from Atlas 66 were transferred into wheat cultivar Century, a susceptible cultivar, and near isogenic lines (NILs) contrasting in Al-tolerance were developed (Carver et al. 1993). The tolerant NIL (OK91G106) was found to confer a high level of Al tolerance in nutrient solution culture and in the field. These are ideal plant materials for differential gene expression studies. The aims of the present study were to identify differential ESTs between NILs contrasting in Al tolerance and to gain a better understanding of the molecular mechanisms resulting in Al tolerance in wheat.

\section{Materials and Methods}

\subsection{Plant materials}

Seeds of the wheat (Triticum aestivum L.) cultivar Century and its Al-tolerant NIL OK91G106 were sown in Metro-Mix 360 soil mix (composition including peat, vermiculite, processed bark ash, nutrient charge, and wetting agent; Hummert International, Earth City, MO, USA) in a growth chamber with a $16 \mathrm{~h}$ photoperiod at $20^{\circ} \mathrm{C}$ and an $8 \mathrm{~h}$ dark period at $16^{\circ} \mathrm{C}$. Plants were watered once a day with Hoagland solution. After $9 \mathrm{~d}$ of normal growth, seedlings were started on Al treatment by supplying the Hoagland solution plus $0.3 \mathrm{mmol} / \mathrm{L}$ $\mathrm{AlK}\left(\mathrm{SO}_{4}\right)_{2}$ at $\mathrm{pH} 4.1$ (Carver et al. 1988). During Al treatment, fresh Al-added Hoagland solution was supplied three times a day. The $\mathrm{pH}$ of the soil solution in Century and OK91G106 was monitored by a glass pH electrode (Metrohm, Herisau, Switzerland) and the continuous measurements were registered with a pen recorder, showing that the $\mathrm{pH}$ around the plant roots was constant. After $48 \mathrm{~h} \mathrm{Al}$ treatment, roots were rinsed gently with tap water and approximately 2 -cm tips were harvested and stored immediately at $-80{ }^{\circ} \mathrm{C}$ for RNA isolation.

\subsection{Measurement of root elongation reduction rate}

Root elongation rates of both wheat lines were examined daily during a 7-d period of Al treatment. Seedlings with a primary root of approximately $10 \mathrm{~mm}$ were transplanted into styrofoam cells floating on the nutrient solution without $\mathrm{Al}^{3+}$ in a plastic tray. Seven days after transplanting, seedlings were transferred to a fresh nutrient solution containing $0.3 \mathrm{mmol} / \mathrm{L} \mathrm{AlK}\left(\mathrm{SO}_{4}\right)_{2}$ at $\mathrm{pH}$ 4.1. Control plants were grown in the same nutrient solution without $\mathrm{AlK}\left(\mathrm{SO}_{4}\right)_{2}$. During $7 \mathrm{~d}$ of $\mathrm{Al}$ treatment, the culture solution was replaced fresh daily and 10 of each of the Al-treated and control seedlings were sampled daily to measure primary root lengths. Daily relative reduction rates of root elongation were measured as the root length ratio between Al-treated and control seedlings for each NIL.

\subsection{Construction of the SSH library}

Total RNA of $48 \mathrm{~h}$ Al-treated root tips from each NIL was extracted with Trizol reagent (Gibco, Gaithersburg, MD, USA). MessengerMaker Kit (Gibco) was used to isolate mRNA. The polymerase chain reaction (PCR)-select cDNA Subtraction Kit (Clontech, Palo Alto, CA, USA) was used for SSH and the Advantage $^{\mathrm{TM}}$ PCR Cloning Kit (Clontech) was used to generate the subtractive library. The NIL OK91G106 served as the tester during the cDNA subtraction process. 


\subsection{Macroarray analysis}

A total of 696 clones was obtained from the subtractive library. The plasmid from each clone was isolated by using the Mini plasmid isolation Kit (Qiagen, Hilden, Germany). The inserted DNA fragment in each plasmid was PCR amplified using M13 primers nested in the cloning vector. The PCR products with high quality from 614 clones were ethanol purified, redissolved in double-distilled (dd) $\mathrm{H}_{2} \mathrm{O}$ and adjusted to the DNA concentration of $0.3 \mu \mathrm{g} / \mu \mathrm{L}$. The purified PCR products were denatured and arrayed directly on a nylon membrane (Amersham Pharmacia, NJ, USA) using a 384-pin replicator (V\&P Scientific, San Diego, CA, USA). For data normalization, the PCR-amplified housekeeping gene actin and a plasmid without insert were assigned to various positions on each array as positive and negative controls, respectively. Subtraction screening of cDNA was performed by both forward subtraction with cDNA (from $48 \mathrm{~h}$ Al-treated OK91G106) and reverse subtraction with cDNA (from $48 \mathrm{~h}$ Al-treated Century) according to the instruction supplied with the Subtracted Library Screen Kit (Clontech).

\subsection{Sequencing and blast search}

Complementary DNA inserts from differential clones were sequenced by using the Thermo Sequenase ${ }^{\mathrm{TM}}$ DyEnamic Direct Cycle Sequencing Kit with 7-deazadGTP (Amersham Pharmacia) on the Li-Cor IR $^{2} 4200$ DNA Analyzer. Putative functions of the cDNA were identified using the BLAST/X alogorithm by comparing the target sequences to those genes with known function in GenBank for similarity.

\subsection{Northern blotting analysis}

Northern blotting analysis of differential ESTs was conducted using NorthernMax Kit (Ambion, Austin, TX, USA) according to the manufacturer's instructions. Hybridization was performed at $42{ }^{\circ} \mathrm{C}$ overnight and the membrane was washed twice at $42{ }^{\circ} \mathrm{C}$ in a $2 \times$ standard saline citrate (SSC) buffer with $0.1 \%$ sodium dodecyl sulfate (SDS) for $10 \mathrm{~min}$ each and twice in a $0.1 \times \mathrm{SSC}$ buffer with $0.1 \% \mathrm{SDS}$ for 15 min each. The membrane was exposed to an X-ray film for approximately $48 \mathrm{~h}$ at $-80^{\circ} \mathrm{C}$ and developed.
Autoradiographs were scanned in a GS-710 Imaging Densitometer (Bio-Rad, Hercules, CA, USA) and the gel images were quantified with associated software. Membranes spotted with cDNA were re-used three to five times by striping the membranes and reprobing with different probes according to the Strip-EZ DNA protocol (Ambion).

\section{Results}

\subsection{Aluminum tolerance of two wheat NILs}

Although Al stress significantly reduced root elongation rates of both Century and Al-tolerant NIL OK91G106, a higher reduction rate was observed in Century than in OK91G106 after Al treatment (Fig. 1). Within $4 \mathrm{~d}$ of Al-stress, the relative root elongation rate of OK91G106 decreased slower than that of Century. The reduction in elongation rate was less than $20 \%$ in OK91G106, whereas it was approximately 50\% in Century. After $7 \mathrm{~d}$ of Al-treatment, the elongation rate reduced to $58 \%$ in OK91G106 and $75 \%$ in Century compared with the untreated controls. In addition, a marked decrease of root elongation rate in Century started $2 \mathrm{~d}$ after Al-treatment, whereas the decrease in OK91G106 started $2 \mathrm{~d}$ later than that of Century (Fig. 1). The significant differences in root elongation rates between these two NILs in response to Al stress are

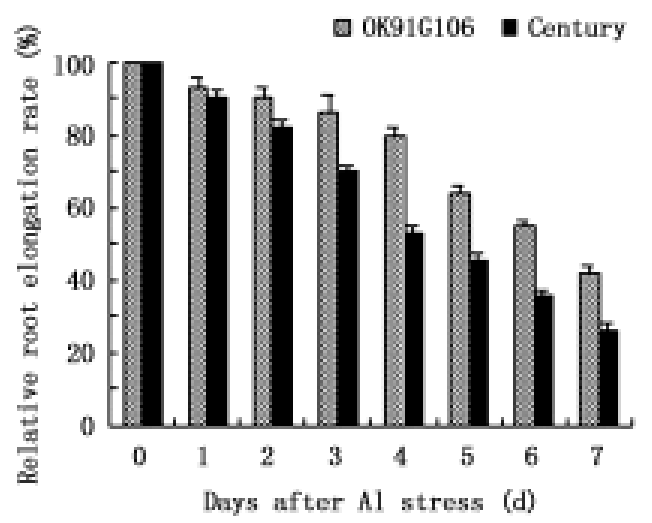

Fig. 1. Relative root elongation rate (\%) of aluminumtreated wheat compared with non-treated control observed in near-isogenic lines Century and OK91G106. Error bars represent standard deviations of mean relative root elongation rate in four replicates. 
consistent with previous results from root tip hematoxylin staining (Carver et al. 1993; Tang et al. 2002).

\subsection{Expression profiles and function classifica-} tions of ESTs

Partial results of macroarray analysis are given in Fig. 2. A representation of the signal intensity ratio of the ESTs of two Al-treated NILs is depicted in Fig. 3 based on macroarray data. The expression signal intensity of most ESTs appeared to be similar between the two NILs treated with $0.3 \mathrm{mmol} / \mathrm{L} \mathrm{AlK}\left(\mathrm{SO}_{4}\right)_{2}$ for $48 \mathrm{~h}$ (Fig. 3). Twenty-five non-redundant ESTs were upregulated and the expression signal intensity of these ESTs in OK91G106 was 1.5-fold greater than that in Century in response to Al treatment (Fig. 3). In our experiments, 614 ESTs on the array derived from the forward SSH library in which the Al-tolerant NIL OK91G106 served as the tester, so the ratio of differentially upregulated ESTs to total tested ESTs reached $4.07 \%$, suggesting that the SSH approach could
$1234 \quad 4321$

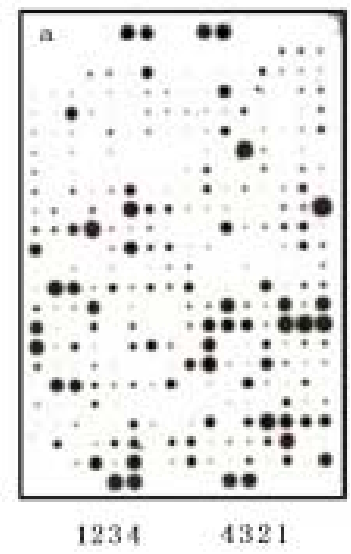

$1234 \quad 4321$

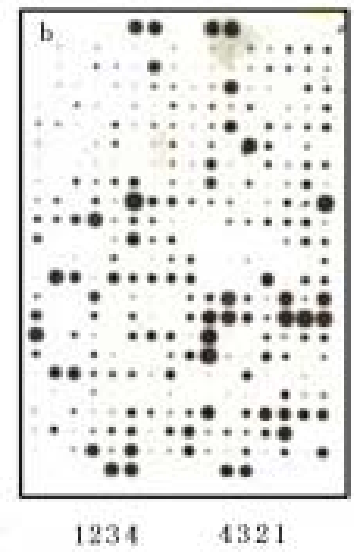

Fig. 2. Macroarray blotting analysis for differentially expressed sequence tags by suppression subtractive hybridization (SSH). PCR-amplified products from bacterial clones of SSH-derived subtracted libraries were dot-blotted onto nylon membranes and were probed with cDNA from $48 \mathrm{~h}$ Al-treated OK91G106 (a) or $48 \mathrm{~h} \mathrm{Al-treated} \mathrm{Cen-}$ tury (b). For data normalization, two sets of control were placed in the top and bottom row of each membrane, where lanes 3 and 4 are the housekeeping gene actin, as a positive control, and lanes 1 and 2 are the plasmid without insert as a negative controls.

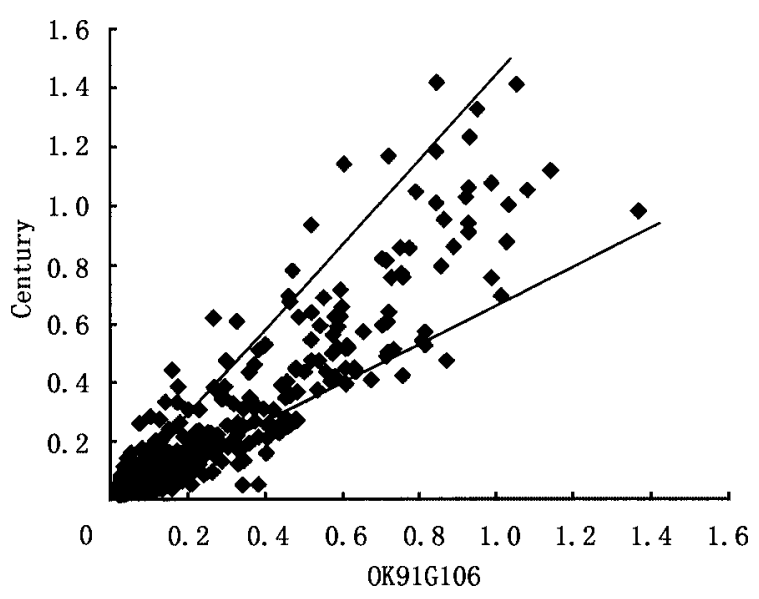

Fig. 3. Scatter plot of signal intensities for all expressed sequence tags (ESTs) on the macroarray. Signal intensities derived from aluminum-treated near-isogenic lines OK91G106 and Century were normalized for each clone on the macroarray and are plotted on the $x$ - and $y$-axes, respectively. The diagonal lines represent 1.5 -fold ratio cutoffs. The data in scatter plot are based on the results from two replicates.

effectively enrich the differentially expressed genes between the wheat NILs.

\subsection{Putative differentially expressed ESTs for Al tolerance}

Several previously reported Al-induced or -regulated genes, including wali5, ubiquitin, and glutathione $S$ transferase, were among those identified in the present study. Table 1 lists differentially expressed ESTs associated with Al tolerance from Al-tolerant NIL OK91G106 according to EST expression analysis and their putative functions based on their sequence homologies with known genes from wheat and other organisms. For most of these ESTs, their expression levels in Al-tolerant NIL OK91G106 were approximately 2.5 -fold higher than those in Al-sensitive NIL Century based on macroarray data. These differentially upregulated ESTs in OK91G106 included those genes that play a significant role in cellular signal transduction (genes for ABA cluster, calcium-dependent protein kinases (CDPKs), and serine/threonine phosphatase), cell wall structure (genes for cell wall protein, proline-rich protein, and cellulose synthase), membrane structure 
Kai XIAO et al.: Nylon Filter Arrays Reveal Differential Expression of Expressed Sequence Tags in Wheat Roots Under Aluminum Stress

Table 1 Differentially upregulated expressed sequence tags in aluminium-tolerant near-isogenic lines OK91G106 under aluminum stress for $48 \mathrm{~h}$

\begin{tabular}{|c|c|c|c|c|c|}
\hline Clone no. & Putative gene & Accession no. & Identity $(\%)$ & $E$-value & Organism \\
\hline FDC10 & ABA-regulated gene cluster & AF085279 & 99 & 1e-167 & Arabidopsis thaliana \\
\hline FDC8 & Calcium dependent protein kinase (CDPK1) & AF072908 & 83 & $2 \mathrm{e}-08$ & Nicotiana tabacum \\
\hline FDC4 & Serine/threonine protein phosphatase (MOJ9.27) & AY042854.1 & 87 & $3 e-22$ & A. thaliana \\
\hline FDC9 & Protein kinase family (At5g18500) & NM-121855.2 & 94 & $7 e-11$ & A. thaliana \\
\hline FDC7 & $\mathrm{ABA}$ and stress-inducible protein $(A s r 1)$ & AF039573 & 87 & $2 e-64$ & Oryza sativa \\
\hline FDC12 & Cellulose synthase-2 (Ces-2) & AF200526 & 88 & $2 e-66$ & Zea mays \\
\hline FDC20 & Cell wall invertase (IVR3) & AF030421.1 & 86 & $9 e-63$ & Triticum aestivum \\
\hline FDC21 & Proline-rich protein & X52472.1 & 82 & $1 e-09$ & T. aestivum \\
\hline FDC19 & Putative proline-rich and glycine protein & $\mathrm{AJ} 24280.1$ & 88 & $3 e-15$ & Sporobolus stapfianus \\
\hline FDC13 & Seven transmembrane protein Mlo8 & AY029319.1 & 87 & $2 e-95$ & Z. mays \\
\hline FDC1 & Superoxide dismutase-Fe & AB014056.1 & 90 & $5 e-64$ & O. sativa \\
\hline FDC11 & Manganese superoxide dismutase (SOD-3) & M33119.1 & 94 & 1e-172 & A. thaliana \\
\hline FDC2 & Glutathione-S-transferase Cla47 & AY064480.1 & 99 & 0 & T. aestivum \\
\hline FDC14 & Putative magnesium transporter (mrs2-2 gene) & ATH297817 & 81 & $7 e-27$ & A. thaliana \\
\hline FDC3 & Triticum aestivum protein of unknown function (wali5) & L 11882.1 & 100 & 1e-153 & T. aestivum \\
\hline FDC5 & Mitochondrial ATP synthase subunit 9 (ATP9) & X15919.1 & 98 & $1 e-165$ & T. aestivum \\
\hline FDC15 & WHTMT26SRR mitochondrial 26S rRNA & M37474.1 & 100 & 0 & T. aestivum \\
\hline FDC18 & WHTTEF1X TEF $1 \alpha$-subunit & M90077.1 & 99 & $1 e-123$ & T. aestivum \\
\hline FDC16 & Polyubiquitin $(R u B Q 1)$ & AF 184279.1 & 91 & $1 e-108$ & O. sativa \\
\hline FDC17 & $\begin{array}{l}\text { Cysteine protease component of protease-inhibitor } \\
\text { complex unknown (5) }\end{array}$ & AB020961.1 & 85 & $3 e-52$ & Z. mays \\
\hline
\end{tabular}

Differentially upregulated expressed sequence tags in aluminum (Al)-tolerant near-isogenic lines OK91G106 under Al stress for $48 \mathrm{~h}$ have been submitted to GenBank in NCBI. ABA, abscisic acid; CDPK1, calcium-dependent protein kinase.

(transmembrane protein gene), reactive oxygen species (ROS; genes coding superoxide dismutase (SOD)$\mathrm{Fe}$, SOD-Mn, and glutathione S-transferase), magnesium transport (putative magnesium transporter), mitochondrial function (genes coding for mitochondrial 26S rRNA, mitochondrial ATP synthase), and protein synthesis and processing (genes coding translation elongation factor (TEF) subunit, polyubiquitin, and protease inhibitor). These genes seem to have function in tolerance to $\mathrm{Al}$ toxicity in the Al-tolerant line tested.

To validate the result from macroarray analysis, eight upregulated ESTs were selected for further Northern analysis (Fig. 4). The trend of EST expression from Northern blotting was similar to that from macroarray analysis (Fig. 4). The result confirmed that the expression of all eight ESTs tested was Al regulated in the Altolerant line OK91G106 and demonstrated that the macroarray analysis was reliable and repeatable.

\section{Discussion}

\subsection{Genes related to organic acid synthesis were not differentially expressed}

Exudation of Al-chelating organic acids, such as malate, oxalate, or citrate, into the rhizosphere has been proposed as a tolerance mechanism to avoid Al toxicity in many plants (Delhaize et al. 1993; Basu et al. 1994; Delhaize and Ryan 1995; Ryan et al. 1995; Pellet et al. 1996; Zhang et al. 2001; Tang et al. 2002). It is postulated that organic acid anions can reach the sites of $\mathrm{Al}$ binding in the apoplast through anion channels by the negative membrane potential and the deep concentration gradient between the cytosol and apoplast or rhizosphere (Delhaize and Ryan 1995). Although a lot of work has reinforced the concept that $\mathrm{Al}$ tolerance in wheat may be based on exudation of malate and its chelation of Al (Delhaize et al. 1993; Carver et al. 1995; 


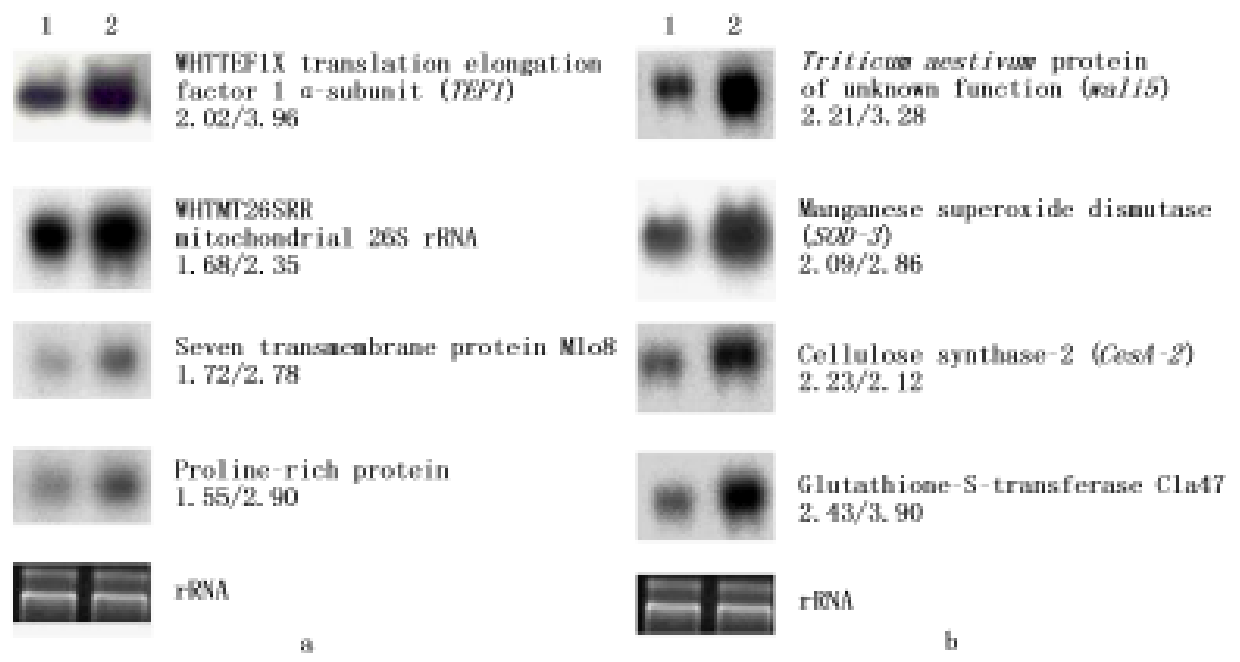

Fig. 4. Northern blotting analysis of randomly selected differentially upregulated expressed sequence tags identified in macroarray analysis. Panel 1 represents 48 h Al-treated Century and panel 2 represents 48 h Al-treated OK91G106. For each cDNA, $a$ and $b$ in the term $a / b$ are the ratios of signal intensities between OK91G106 and Century from Northern blotting (a) and macroarray analysis (b), respectively.

Delhaize and Ryan 1995), differentially upregulated genes directly involved in the malate synthesis pathway were not identified in the Al-tolerant NIL OK91G106 under Al stress. Up to date, approximately $20 \mathrm{Al}$-induced or regulated genes have been reported (Milla et al. 2002), but none of them can be related directly to the biosysthesis of organic acids. Some evidence indicates that $\mathrm{Al}$ stress does not affect the activities of isocitrate dehydrogenase, phosphoenolpyruvate carboxylase, and malate dehydrogenase, the important enzymes regulating the synthesis of organic acids in wheat (Li et al. 2000). Ma et al. (2000) found that Alinduced secretion of malate in wheat and buckwheat has a pattern with no discernible delay between the addition of $\mathrm{Al}$ and the onset of the release of malate, which is caused by the activation of an anion channel for organic acids. These results indicate that there seem to be no induced or regulated genes involved in the synthesis of malate and other organic acids in wheat under Al stress. The greater secretion of organic acids in Al-tolerant wheat cultivars under Al stress could be due to the activation of a related anion channel for organic acids (Ma et al. 2000) or an aluminum-activated malate transporter (Sasaki et al. 2004).

\subsection{A signal pathway response to Al stress in Al- tolerant NIL}

Several signal transduction genes were differentially expressed in the Al-tolerant NIL after Al stress, including an abscisic acid (ABA) cluster gene, a CDPK gene, and a serine/threonine phosphatase gene. This result indicates that a signaling pathway may be activated when Al-tolerant wheat is challenged with $\mathrm{Al}$ stress. The plant hormone ABA mediates many vital processes in plant growth and development (Hagenbeek et al. 2000). Several ABA-signaling genes have been cloned and shown to encode protein phosphatases and transcription factors (Finkelstein et al. 1998; Luerssen et al. 1998). Meanwhile, as a class of $\mathrm{Ca}^{2+}$-binding sensor proteins, CDPKs can bind directly calcium to act as a ubiquitous second messenger in eukaryotic signal transduction cascades (Cheng et al. 2002). Several lines of evidence suggest that CDPKs may mediate abiotic stress-signaling pathways (Sheen 1996; Sajio et al. 2000, 2001). These results indicate that the differentially expressed wheat $A B A$ cluster genes and $C D P K$ genes in Al-tolerant NIL OK91G106 may play a major role in intercepting 
the Al-stress signal and regulate the activity of some protein kinases through eliciting the differentially expressed serine/threonine phosphatase gene, which regulates the phosphorylation status of biochemical enzymes in the resistant NIL.

\subsection{Genes for cell wall structure and function are involved in Al tolerance}

Several ESTs related to cell wall structure and function were differentially expressed in Al-tolerant NIL. These ESTs included a cell wall protein, a proline-rich protein, and a cellulose synthase. Some results indicated that $\mathrm{Al}$ could rapidly binds to the walls of root cells when applied externally (Delhaize et al. 1993). The $\mathrm{Al}^{3+}$ ion binds mainly to the negative-charged carboxylic groups of the pectic matrix in the cell wall; as a result, it reduces the movement of water and mineral nutrients through cell wall interstices and impairs the physical properties of the cell wall, resulting in low extensibility and permeability of the cell wall (Pritchard 1994). The differential expression of genes encoding cell wall and proline-rich proteins in the Al-tolerant line may increase wheat tolerance to Al toxicity through improving cell wall functions, such as improving the extensibility and permeability of the cell wall and increasing the movement of water and mineral nutrients through cell wall interstices. In addition, it has been reported that Al-stressed wheat roots typically appear shorter and thicker, which may elicit secondary responses potentially detrimental to overall growth and development of a wheat plant (Carver et al. 1995). In the present study, relative improvement of root growth rate in the Al-tolerant NIL OK91G106 (Fig. 1) than in Century may be attributed, to some extent, to overexpression of the cellulose synthase gene $\operatorname{Ces} A 3$, a key enzyme promoting cell elongation.

\subsection{Improvement of membrane stability under} Al stress may contribute to Al tolerance in Al-tolerant NIL

Under Al stress, the outer surface of the plasma membrane and cell wall pectin are considered to be two major targets of $\mathrm{Al}$ toxicity because $\mathrm{Al}$ ions preferentially form electrostatic bonds with oxygen donor ligands, such as carboxylate and phosphate groups (Yamamoto et al. 2001). The plasmalemma is a vulnerable site for binding Al ions (Carver et al. 1995). The binding of Al to the membrane can cause rigidification of the plasma membrane (Deleers et al. 1986), peroxidation of membrane lipids, and an increase in membrane permeability by increasing the ratio of phosphatidylcholine to phosphatidylethanolamine (Lindberg et al. 1993). Hence, metabolism in the plasma membrane can be significantly altered under Al stress. However, transgenic Arabidopsis plants overexpressing Al-induced tobacco glutathione S-transferase gene (parB) and anionic peroxidase gene (NtPox) significantly restricted lipid peroxidation in cell membrane regions, showed much lower induction of malondialdehyde (MDA), and maintained normal membrane function under Al stress (Ezaki et al. 2001). In the present study, the genes encoding an SOD-Fe, an SOD-Mn, and a glutathione S-transferase were involved scavenging of ROS and have been identified to be upregulated in the Al-tolerant NIL, suggesting that differential expression of these genes may play a role in stabilizing plasma membrane structure and maintaining membrane function under Al stress.

\subsection{Magnesium transporter seems to affect Al tolerance in wheat}

Magnesium $\left(\mathrm{Mg}^{2+}\right)$ is the most abundant divalent cation in a living plant cell. In higher plants, $\mathrm{Mg}^{2+}$ stabilizes membranes, regulates many cellular enzymes, and acts as an essential component of chlorophyll molecules (Li et al. 2001). Meanwhile, the concentration of free ionized $\mathrm{Mg}$ can change rapidly in response to environmental stimuli and plays an important role in cell division, growth, and development (MacDiarmid et al. 1998). When a plant grows in soil with a high concentration of $\mathrm{Al}$ at a low $\mathrm{pH}$, one common result is the perturbation of ionic steady state, leading to an imbalance of ion homoestasis in cells and a deficiency of essential nutrients, like $\mathrm{Mg}^{2+}, \mathrm{Ca}^{2+}$, or $\mathrm{Mo}^{2+}$ (Carver et al. 1995). In a family such as Poaceae, long-term exposure of plants to $\mathrm{Al}^{3+}$ causes significant $\mathrm{Mg}^{2+}$ deficiency and, therefore, leads to poor plant growth and 
low yield (Tan et al. 1991). Conversely, increasing $\mathrm{Mg}^{2+}$ uptake can ameliorate $\mathrm{Al}^{3+}$ toxicity (Tan et al. 1991; Matsumoto 2000). Increased activity of the $\mathrm{Mg}^{2+}$-transport system confers yeast resistance to $\mathrm{Al}^{3+}$ and also overcomes the inhibition of cation uptake by Al (MacDiarmid et al. 1998). In the present study, the putative magnesium transporter was identified in the Al-tolerant NIL and its upregulated expression increases wheat tolerance to $\mathrm{Al}$ toxicity. Therefore, this gene may play an important role in enhancing wheat tolerance to Al toxicity by increasing $\mathrm{Mg}^{2+}$ uptake and improving ion homeostasis in Al-stressed cells. However, most studies on $\mathrm{Mg}^{2+}$ transporters have been performed in yeast. Further investigation of $\mathrm{Mg}^{2+}$ transporters in wheat may shed light on the mechanisms of wheat tolerance to $\mathrm{Al}$ toxicity.

In summary, our results indicate that wheat tolerance to $\mathrm{Al}$ stress involves complicated defense-related signaling and metabolic pathways. Genes related to primary reactions (such as signal transduction and oxidative stress alleviation) and secondary reactions (such as membrane structure, function, and ion transport) were differentially upregulated in the Al-tolerant NIL in response to $\mathrm{Al}$. Under $\mathrm{Al}$ stress, genes directly related to the synthesis of malate and other organic acids were not detected.

\section{References}

Basu U, Godbold D, Taylor GJ (1994). Aluminum resistance in Triticum aestivum associated with enhanced exdution of malate. J Plant Physiol 144, 747-753.

Basu U, McDonald-Stephens JL, Archambault DJ et al. (1997). Genetic and physiological analysis of doubled-haploid, aluminum resistant lines of wheat provide evidence for the involvement of a $23 \mathrm{kD}$, root exudates polypeptide in mediating resistance. Plant Soil 196, 283-288.

Carver BF, Ownby JD (1995). Acid soil tolerance in wheat. $A d v$ Agron 54, 117-173.

Carver BF, Inskeep WP, Wilson NP, Westerman RL (1988). Seedling tolerance to aluminum toxicity in hard red winter wheat germplasm. Crop Sci 28, 463-467.

Carver BF, Whitmore WE, Smith EL, Bona L (1993). Registration of four aluminum-tolerant winter wheat germplasms and two susceptible near-isolines. Crop Sci 33, 1113-1114.

Cheng SH, Willmann MR, Chen HC, Sheen J (2002). Calcium signaling through protein kinases: The Arabidopsis calciumdependent protein kinase gene family. Plant Physiol 129, 469-485.

Cruz-Ortega R, Cusman JC, Ownby J (1997). cDNA clones encoding 1, 3- $\beta$-glucanase and a fimbrin-like cytoskeletal protein are induced by $\mathrm{Al}$ toxicity in wheat roots. Plant Physiol 114, 1453-1460.

Deleers M, Servais JP, Wulfert E (1986). Neurotoxic cations induce membrane rigidification and membrane fusion at micromolar concentrations. Biochim Biophys Acta 855, 271276.

Delhaize E, Ryan PR (1995). Aluminum toxicity and tolerance in plants. Plant Physiol 107, 315-321.

Delhaize E, Craig S, Beaton CD, Bennet RJ, Jagadish V, Randall PJ (1993a). Aluminum tolerance in wheat (Triticum aestivum L.). I. Uptake and distribution of aluminum in root apices. Plant Physiol 103, 685-693.

Delhaize E, Ryan PR, Randall PJ (1993b). Aluminum tolerance in wheat (Triticum aestivum L.). II. Aluminum-stimulated excretion of malic acid from root apices. Plant Physiol 103, 695-702.

Diatchenko L, Lau YFC, Campbell PA et al. (1996). Suppression subtractive hybridization: A method for generating differentially regulated or tissue-specific cDNA probes and libraries. Proc Natl Acad Sci USA 93, 6025-6030.

Diatchenko L, Lukyanov S, Lau YFC, Siebert D (1998). Suppression subtractive hybridization: A versatile method for identifying differentially expressed genes. Methods Enzymol 303, 349-380.

Ezaki B, Katsuhara M, Kawamura M, Matsumoto H (2001). Different mechanisms of four aluminum (Al)-resistant transgenes for Al toxicity in Arabidopsis. Plant Physiol 127, 918-927.

Finkelstein RR, Wang ML, Lynch TJ, Rao S, Goodman HM (1998). The Arabidopsis abscisic acid response locus $A B I 4$ encodes an APETALA 2 domain protein. Plant Cell 10, 10431054.

Hagenbeek D, Ralph SQ, Christopher DR (2000). Trivalent ions activate abscisic acid-inducible promoters through an 
Kai XIAO et al.: Nylon Filter Arrays Reveal Differential Expression of Expressed Sequence Tags in Wheat Roots Under Aluminum Stress

ABI1-dependent pathway in rice protoplasts. Plant Physiol 123, 1553-1560.

Horst WJ (1995). The role of the apoplast in aluminum toxicity and resistance of higher plants: A review. Z Pflanzenernahr Bodenk 158, 419-428.

Jones DL, Kochian LV (1995). Aluminum interaction with plasma membrane lipids and enzyme metal binding sites and its potential role in aluminum cytotoxicity. FEBS Lett 400, 51-57.

Li L, Tutone AF, Drummond RSM, Gardner RC, Luan S (2001). A novel family of magnesium transport genes in Arabidopsis. Plant Cell 13, 2761-2775.

Li XF, Ma JF, Matsumoto H (2000). Pattern of aluminuminduced secretion of organic acids differs between rye and wheat. Plant Physiol 123, 1537-1543.

Lindberg S, Griffiths G (1993). Aluminum effects on ATPase activity and lipid composition of plasma membranes in sugar beet roots. $J$ Exp Bot 44, 1543-1550.

Luerssen K, Kirik V, Herrmann P, Misera S (1998). Fusca3 encodes a protein with a conserved Vp1/Abi3-like B3 domain which is of functional importance for the regulation of seed maturation in Arabidopsis thaliana. Plant J 15, 755764.

Ma JF, Taketa S, Yang ZM (2000). Aluminum tolerance genes on the short arm of chromosome $3 \mathrm{R}$ are linked to organic acid release in triticale. Plant Physiol 122, 687-694.

MacDiarmid CW, Gardner RC (1998). Overexpression of the Sacchromyces cerevisiae magnesium transport system confers resistance to aluminum ion. J Biol Chem 273, 17271732.

Matsumoto H (2000). Cell biology of aluminum toxicity and tolerance in higher plants. Int Rev Cytol 200, 1-46.

Milla MAR, Butler E, Huete AR, Wilson CF, Anderson O, Gustafson JP (2002). Expressed sequence tag-based gene expression analysis under aluminum stress in rye. Plant Physiol 130, 1706-1716.

Pellet DM, Papernik LA, Kochian LV (1996). Multiple aluminum-resistance in wheat: Roles of root apical phosphate and malate exudation. Plant Physiol 112, 591-597.

Pritchard J (1994). The control of cell expansion in roots. New
Phytol 127, 3-26.

Ryan PR, Delhaize E, Randall PJ (1995). Characterization of AL-stimulated efflux of malate from the apices of Al-tolerant wheat roots. Planta 196, 103-110.

Sajio Y, Hata S, Kyozuka J, Shimanoto K, Izui K (2000). Overexpression of a single $\mathrm{Ca}^{2+}$-dependent protein kinase confers both cold and salt/drought tolerance on rice plants. Plant $J$ 23, 319-327.

Sajio Y, Kinoshita N, Ishiyama K et al. (2001). A Ca ${ }^{2+}$-dependent kinase that endows rice plants with cold-and salt-stress tolerance function in vascular bundles. Plant Cell Physiol 42, $1228-1233$.

Sasaki T, Yamamoto Y, Ezaki B et al. (2004). A wheat gene encoding an aluminum-activated malate transporter. Plant $J$ 37, 645-653.

Schenk PM, Kazan K, Wilson I et al. (2000). Coordinated plant defense responses in Arabidopsis revealed by microarray analysis. Proc Natl Acad Sci USA 97, 11655-11660.

Sheen J (1996). $\mathrm{Ca}^{2+}$-dependent protein kinases and stress signal transduction in plants. Science 274, 1900-1902.

Snowden KC, Gardner RC (1993). Five genes induced by aluminum in wheat (Triticum aestivum L.) roots. Plant Physiol 103, 855-861.

Tan K, Keltjens WG, Findenegg GR (1991). Role of magnesium in combination with liming in alleviating acid-soil stress with the aluminum-sensitive sorghum genotype CV323. Plant Soil 136, 65-72.

Tang Y, Garvin DF, Kochian LV, Sorrells ME, Carver BF (2002). Physiological genetics of aluminum tolerance in the wheat cultivar Atlas 66. Crop Sci 42, 1541-1546.

Von Uexkull HR, Mutert E (1995). Global extent, development and economic impact of acid soils. Plant Soil 171, 1-15.

Yamamoto Y, Kobayashi Y, Matsumoto H (2001). Lipid peroxidation is an early symptom triggered by aluminum, but not the primary cause of elongation inhibition in pea roots. Plant Physiol 125, 199-208.

Zhang WH, Ryan PR, Tyerman SD (2001). Malate-permeable channels and cation channels activated by aluminum in the apical cells of wheat roots. Plant Physiol 125, 1459-1472. 
Appendix I: Expressed sequence tags submitted to GenBank in NCBI

\begin{tabular}{|c|c|c|c|}
\hline dbEST_Id & User_Id & GenBank_Accn & Clone No. \\
\hline 19875630 & EST001 & CF569140 & FDC1 \\
\hline 19875631 & EST002 & CF569141 & FDC2 \\
\hline 19875632 & EST003 & CF569142 & FDC3 \\
\hline 19875633 & EST004 & CF569143 & FDC4 \\
\hline 19875634 & EST005 & CF569144 & FDC5 \\
\hline 19875636 & EST007 & CF569146 & FDC7 \\
\hline 19875637 & EST008 & CF569147 & FDC8 \\
\hline 19875638 & EST009 & CF569148 & FDC9 \\
\hline 19875639 & EST010 & CF569149 & FDC10 \\
\hline 19875640 & EST011 & CF569150 & FDC11 \\
\hline 19875641 & EST012 & CF569151 & FDC12 \\
\hline 19875642 & EST013 & CF569152 & FDC13 \\
\hline 19875643 & EST014 & CF569153 & FDC14 \\
\hline 19875644 & EST015 & CF569154 & FDC15 \\
\hline 19875645 & EST016 & CF569155 & FDC16 \\
\hline 19875646 & EST017 & CF569156 & FDC17 \\
\hline 19875647 & EST018 & CF569157 & FDC18 \\
\hline 19875648 & EST019 & CF569158 & FDC19 \\
\hline 19875649 & EST020 & CF569159 & FDC20 \\
\hline 19875650 & EST021 & CF569160 & FDC21 \\
\hline 19875696 & EST067 & CF569206 & FDC67 (unknown function) \\
\hline 19875697 & EST068 & CF569207 & FDC68 (unknown function) \\
\hline 19875698 & EST069 & CF569208 & FDC69 (unknown function) \\
\hline 19875699 & EST070 & CF569209 & FDC70 (unknown function) \\
\hline 19875700 & EST071 & CF569210 & FDC71 (unknown function) \\
\hline
\end{tabular}

